\title{
Phytochemicals Levels and Antioxidant Capacities of Figs Flowers Fruits
}

\author{
Mohammed Messaoudi (이, Maroua Merah
}

University Dr Moulay Tahar, PO Box 138 Al-Nasr District 20000, Saida -Algeria

Article history:- Received: 7 Dec 2019; Revised: 5 Apr 2020; Accepted: 16 Jun 2020; Published online: 31 Jul 2020

\begin{abstract}
Since antiquity, phenolic compounds produced by plants were known as free radical scavengers and as powerful antioxidants. Huge interest has been made by researchers to the traditional uses of medicinal plants against illnesses related to oxidative stress. This study measures the correlation that can be existed between the antioxidant capacity and phytochemicals levels of four varieties of Ficus carica fruits, figs flowers or "Bakor" as called locally in Algeria. Therefore, extracts were assessed for determining their antioxidative potentials using both test of total antioxidant capacity and DPPH (1,1-diphenyl-2-picrylhydrazyl) free radical scavenging test followed by quantitative phytochemical analysis to estimate the total flavonoid level (TFL), the total phenolic level (TPL), the total anthocyanin level (TAL) and the condensed tannins level of plants methanolic extracts. A positive correlation was observed between phenolics content and the antioxidant capacity of figs flowers methanol extracts. The methanolic extract of Bechar (MeOH Var.2) chelated $87.9 \pm 1.23 \%$ of the DPPH free radical with IC50 value equal to $0.185 \mathrm{mg} / \mathrm{g}$ DW. A high antioxidant ability of almost all extracts is, probably, related to the appreciable rates of flavonoids, phenolics and tannins showed by those fig extracts. The highest value of phenolics level was detected among the variety 1 methanolic extract of Bechar (MeOH Var.1) of $10.4 \mathrm{mg} \mathrm{GAE} / \mathrm{g}$ DW.
\end{abstract}

Keywords: Antioxidant capacity; Bakor; figs flowers; Ficus carica; Methanol extracts; DPPH.

घCorresponding author, email: microbiologistemed@yahoo.fr

\section{Introduction}

Phytochemicals, including phenolics, flavonoids, flavonols, ascorbic acid, lignin, xanthones, stilbenes, etc., are plant-based secondary metabolites, which are associated with the protection of human health against chronic diseases [1, 2, 3, 4]. The relative importance of medicinal and food plant species can be assessed by their use-value. Plant species with more traditional uses exhibit high use value compared to those which have fewer ones [5]. Nowadays, medicinal plants considered as an important source of drugs as about $25 \%$ of the drugs prescribed worldwide derive from plants [6].

Fig tree Ficus carica Linn. originated in the Middle East areas such as Syria, Asia Minor, and Iran, then, it was spread to the Mediterranean basin countries by old humans $[7,8]$. It belongs to the family of Moraceae. F. carica L. is one of the unique widely spread Ficus species that has edible fruits with high commercial value. The production of commercial fig is situated in regions that possess a Mediterranean climate [9].
F. carica L. has three figs yields, Early fig stays on the tree; Late fig of autumn or figs flowers carries from August to winter and is locally known as Bakor and the green or winter figs $[10,11]$. Oxidative stress is an inequality between prooxidants and antioxidants in favor of the first contributing to the appearance of several pathologies. The uncontrolled oxygen species resulted will have serious and severe consequences for the human organism [12]. Several studies focus on natural antioxidant sources to find new effective, safe and cheap antioxidants as there is a strong relationship between the decrease of certain chronic diseases and plants-produced antioxidants [13]. Fruits are essential functional foods that maintain the human vital functions as they providing a well-balanced diet [14]. Viewing the biological properties of $F$. carica fruits, our study focuses on the correlation between phytochemicals contents and antioxidant capacity of dried fruits methanolic extracts of figs flowers or "Bakor" originated of four different varieties of F. carica. Two varieties of Bechar and the two others from Mascara. 


\section{Materials and Methods}

\section{Collection of Plant Samples}

Fruits from four different varieties of $F$. carica figs flowers or "Bakor" as called locally were collected between May and August 2018. Two varieties from Bechar located at the Southwest of Algeria: Var.1 (Lahmar), Var.2 (Ouakda). The other two ones from Mascara situated at the North of Algeria: Var.3 (El Bordj), Var.4 (Ghriss). Plants specimens were identified by the Laboratory of Biotoxicology, Pharmacognosy and Biological Valorisation of Plants (University of Saida).

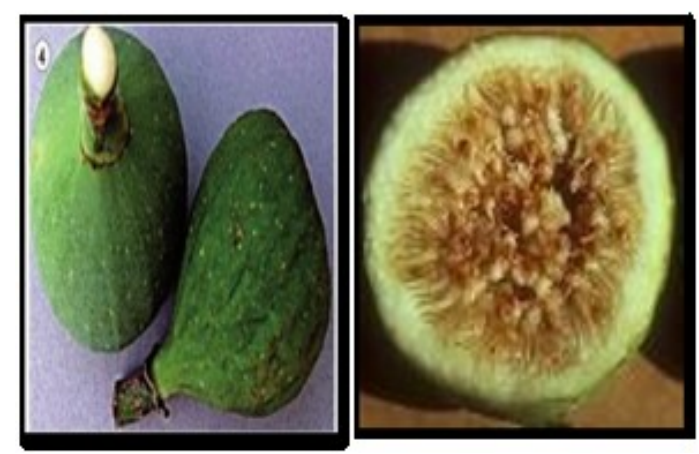

Figure 1. Fruit of Ficus carica L. (Left: whole fruit; Right: cross-section) [15, 16].

\section{Preparation of Methanolic Extracts}

Four samples of fig flowers were air-dried and crushed. After, $1 \mathrm{~g}$ of $F$. carica fruits was soaked, under ultrasound, using pure methanol $(20 \mathrm{~mL})$ for $24 \mathrm{~h}$. Plants extracts were filtered, concentrated and stored at $4^{\circ} \mathrm{C}$ until used (MeOH Var.1, $\mathrm{MeOH}$ Var.2, $\mathrm{MeOH}$ Var.3, $\mathrm{MeOH}$ Var.4) [17].

\section{Phytochemical screening}

Chemical products and reagents purchased from Merck Company, Darmstadt, Germany and phytochemical screening tests were repeated for three times.

\section{Determination of percentage yield}

The percentage yield was calculated for each extract using the formula:

Percentage yield $(\%)=a / b \times 100$

Where: $(a)=$ the dry weight of extract, $(b)=$ soaked samples material [18].

\section{Determination of Total Flavonoids Level (TPL)}

To measure the total flavonoids level, volumes of $2 \mathrm{~mL}$ from both plant extracts and 2\% ethanolic solution of aluminum trichloride $\left(\mathrm{AlCl}_{3}\right)$ were mixed and incubated $10 \mathrm{~min}$ at room temperature. After measurement of absorbance at $430 \mathrm{~nm}$, TFL resulted in mg quercetin per g dry weight [19].

\section{Determination of Total Phenolic Level (TPL)}

Total phenolics level was estimated via FolinCiocalteu's reagent. A mixture of sodium carbonate solution $(2 \mathrm{~mL}, 2 \%)$ and $0.1 \mathrm{~mL}$ of plant extract was incubated for $5 \mathrm{~min}$. Then, a volume of $100 \mu \mathrm{L}$ FolinCiocalteu's reagent was added. The mixture was incubated for $30 \mathrm{~min}$ and absorbance was read at 700 $\mathrm{nm}$ to determine the TPL as mg gallic acid per $\mathrm{g}$ dry weight (mg GAE/g) [20].

\section{Determination of Total Anthocyanins Level (TAL)}

The $\mathrm{pH}$ differential method was used to deduce total anthocyanins level, by which, the absorbance of the reaction solution was measured at both $510 \mathrm{~nm}$ and $700 \mathrm{~nm}$ at two $\mathrm{pH} 1.0$ then $\mathrm{pH} 4.5$ using buffer systems: hydrochloric acid $(0.2 \mathrm{M})$ and sodium acetate $(1 \mathrm{M})$.

$\mathrm{A}=\left(\mathrm{A}_{510}-\mathrm{A}_{700}\right)_{\mathrm{pH} 1,0}-\left(\mathrm{A}_{510}-\mathrm{A}_{700}\right)_{\mathrm{pH} 4,5}$

$\mathrm{TAL}=[(\mathrm{A} \times \mathrm{MW} \times \mathrm{DF}) / \mathrm{MA}] \times 100$

A: absorbance; MW: molar mass; DF: dilution factor; MA: molar absorption.

TAL was expressed as mg cyanidin-3-glucoside per $\mathrm{g}$ of dry weight (mg C3G/g) [2, 21].

\section{Determination of Condensed Tannins Level (CTL)}

The vanillin test was used to estimate the Condensed Tannins Level (CTL). The mixture contained methanolic solution of vanillin $(4 \%, \mathrm{w} / \mathrm{v})$, methanol $(37 \%, \mathrm{v} / \mathrm{v}), \mathrm{HCl}(8 \%, \mathrm{v} / \mathrm{v})$, at equal volume was kept at $30^{\circ} \mathrm{C}$ until used. Then, a solution of $1500 \mu \mathrm{l}$ of vanillin methanolic solution was added to $50 \mu \mathrm{l}$ of plant extracts and $750 \mu \mathrm{l}$ of concentrated $\mathrm{HCl}$ was incubated for $20 \mathrm{~min}$. The absorbance was read at $550 \mathrm{~nm}$ and compared to a blank of equal volumes of both $37 \%$ methanol and $8 \% \mathrm{HCl}$. Results were expressed in mg of catechin equivalent per gram of the dry weight (mg CE/g) [22, 23, 24].

\section{Tests of antioxidant capacity}

The antioxidant capacity of the four varieties were evaluated using free radical scavenging test (DPPH) and total antioxidant capacity (TAC). 


\section{DPPH free radical scavenging test}

DPPH scavenging test was used to estimate the capacity of each extract to scavenge hydrogen atom generated of 2,2-diphenyl-1-picrylhydrazil radical. A mixture of $1 \mathrm{~mL}$ of $100 \mu \mathrm{M}$ methanol solution of the free radical DPPH and different concentrations of each extract was incubated $20 \mathrm{~min}$. The absorbance of the solution was read at $517 \mathrm{~nm}$ and compared to the blank that contained both $1 \mathrm{~mL}$ of DPPH methanolic solution and $0,1 \mathrm{~mL}$ of methanol solvent $[25,26]$. The inhibition percentage (\% IP) of $\mathrm{DPPH}$ solution was estimated by the following formula:

$\left.\% \mathrm{IP}=\left[\left(\mathrm{At}_{0}-\mathrm{At}_{20}\right) / \mathrm{At} \mathrm{t}_{0} \times 100\right)\right]$

Where, $A t_{0}=$ Absorbance of the blank solution after 20 min. $A_{2}=$ Absorbance of each sample after 20 min. Then, the concentration of an extract that allowing to $50 \%$ inhibition of DPPH solution (IC50) was obtained graphically. The less is the IC50, the higher is the antioxidant capacity. A positive control with various concentrations was prepared by the methanolic solution of ascorbic acid [27].

\section{Total Antioxidant Capacity (TAC)}

The test of phosphomolybdenum reagent allows the determination of Total Antioxidant Capacity (TAC) of plant samples. A mixture that contains a $3 \mathrm{~mL}$ volume of a solution of ammonium molybdate reagent $(4 \mathrm{mM})$, sulphuric acid $(0.6 \mathrm{M})$ and sodium phosphate $(28 \mathrm{mM})$ added to a volume $0.3 \mathrm{~mL}$ of each extract was incubated at $95^{\circ} \mathrm{C}$. After, $90 \mathrm{~min}$, the absorbance was measured at $695 \mathrm{~nm}$ against a control solution prepared under the same conditions, constituted of $0.3 \mathrm{~mL}$ of methanol and 3 $\mathrm{mL}$ of all the reagents used before. Total Antioxidant Capacity expressed as mg ascorbic acid per g dry weight (mg AAE / g). A calibration curve with various concentrations was prepared using ascorbic acid [28].

\section{Statistical analysis}

The experimental data obtained from the TFL, TPL, TAL, CTL and antioxidant capacity tests were expressed as means \pm standard deviation. Statistical analysis of data was performed using Microsoft Excel. Statistical differences were estimated, Oneway ANOVA and student's t-test were used. The correlation coefficient of antioxidant capacities as determined by the Pearson test. Values are to be statistically significant at $p<0.05$.

\section{Results and Discussion}

Total flavonoids level, total anthocyanins level, total phenolics level, condensed tannins level of fig flowers fruits (Bakor) methanolic extracts are presented in Figure 2.

The total phenolics level of the four extracts varied from 4.7 to $10.4 \mathrm{mg}$ GAE/g DW. The highest level was significantly $(p<0.05)$ conferring to the variety 1 methanolic extract of Bechar (MeOH Var.1) and the lowest in the extract $\mathrm{MeOH}$ Var.3 of Mascara (See Figure 2).

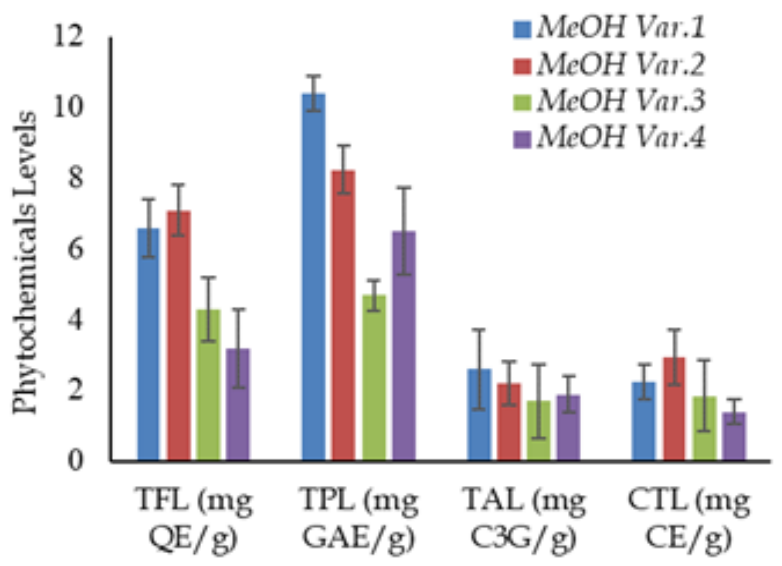

Figure 2. Levels of various phytochemicals of fig flowers fruits methanolic extracts. $\mathrm{MeOH}$ Var.1; $\mathrm{MeOH}$ Var.2: Variety 1, 2 Bakor (Fig flowers) of Bechar. $\mathrm{MeOH}$ Var.2; $\mathrm{MeOH}$ Var.3: Variety 2 Bakor of Mascara. TFL: Total Flavonoids Level, TAL: Total Anthocyanins Level, TPL: Total phenolics Level. CTL: Condensed Tannins Level. mg QE/g : quercetin equivalents; $\mathrm{mg} \mathrm{C} 3 \mathrm{G} / \mathrm{g}$ : cyanidin-3-glucoside equivalents; mg GAE /g : acid gallic equivalents; mg CE/g: catechin equivalent.

The extract of Bechar MeOH Var.2 has the highest Total flavonoids value 7.1 mg QE/g DW while $\mathrm{MeOH}$ Var.4 has the lowest one of $3.2 \mathrm{mg}$ QE/g DW. An important total anthocyanin levels were detected in $\mathrm{MeOH}$ Var. 1 of $2.6 \mathrm{mg} \mathrm{C} 3 \mathrm{G} / \mathrm{g}$ DW compared to the methanolic extract of mascara $\mathrm{MeOH}$ Var. 3 which has a low value $(1.7 \mathrm{mg}$ C3G/g DW). A statistical significant differences existed on phytochemicals levels between plant samples $(p<0.05)$.

Total phenolics amounts resulted in F. carica skin extracts ranged between 28.6 and $211.9 \mathrm{mg} \mathrm{GAE} \mathrm{/}$ $100 \mathrm{~g} \mathrm{FW}$ and between 24 and $237 \mathrm{mg} \mathrm{GAE} \mathrm{/} 100 \mathrm{~g}$ FW [21, 29]. The considerable phytochemicals levels obtained can be explained by the sonication extraction using pure methanol as solvent and as such, is not an ignored proposition as the extraction of flavones, polyphenols, anthocyanins, tannins can 
be very good using alcohol such as methanol solvent [30].

Furthermore, the special climate conditions such as the low monthly rainfall and the high temperature characterizing the harvest year of plant samples can also affect widely their phytochemicals amounts. According to Vallejo et al. 2012, the skin of the early fig fruit (first crop) is richer in phenolic components than late fruit (second crop) possibly as a consequence of climatic factors [31].

Figures 3, 4 and 5 illustrate the total antioxidant capacity and the \% inhibition of DPPH.

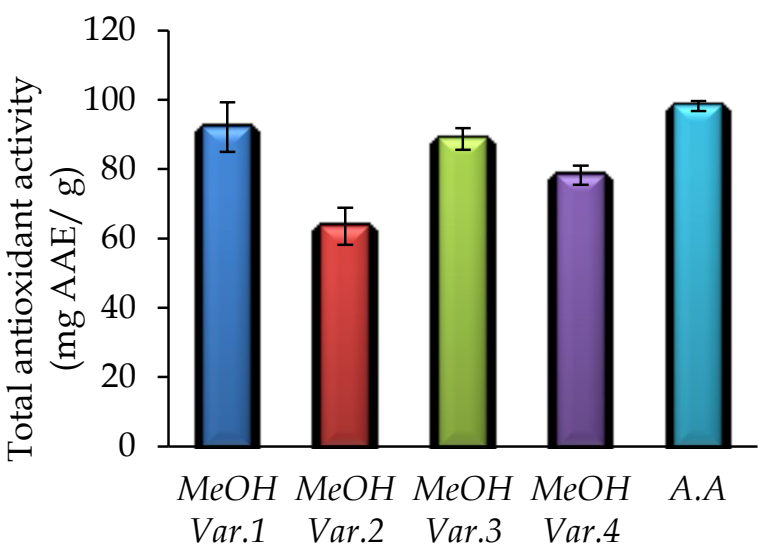

Figure 3. Total antioxidant capacity of fig flowers fruits methanolic extracts. $\mathrm{MeOH}$ Var.1; $\mathrm{MeOH}$ Var.2: Variety 1, 2 Bakor (Fig flowers) of Bechar. $\mathrm{MeOH}$ Var.3; $\mathrm{MeOH}$ Var.4: Variety 3, 4 Bakor of Mascara.

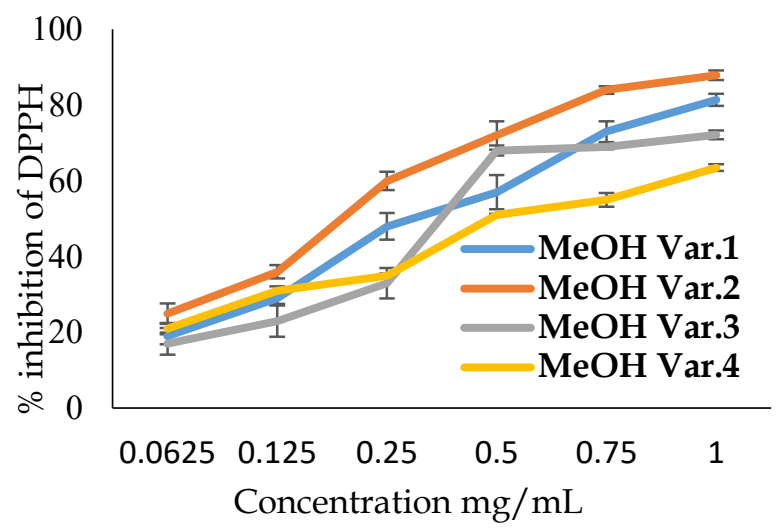

Figure 4. DPPH radical scavenging activity of fig flowers fruits methanolic extracts. $\mathrm{MeOH}$ Var.1; $\mathrm{MeOH}$ Var.2: Variety 1, 2 Bakor (Fig flowers) of Bechar. MeOH Var.3; MeOH Var.4: Variety 3, 4 Bakor of Mascara

The inhibition concentration value that exhibits 50\% of radical scavenging activity for different varieties of extracts (Table $\mathbf{1}$ ). Table 2 summarizes the correlation coefficients among antioxidant tests, total flavonoid level, total anthocyanins level and total phenolic level.

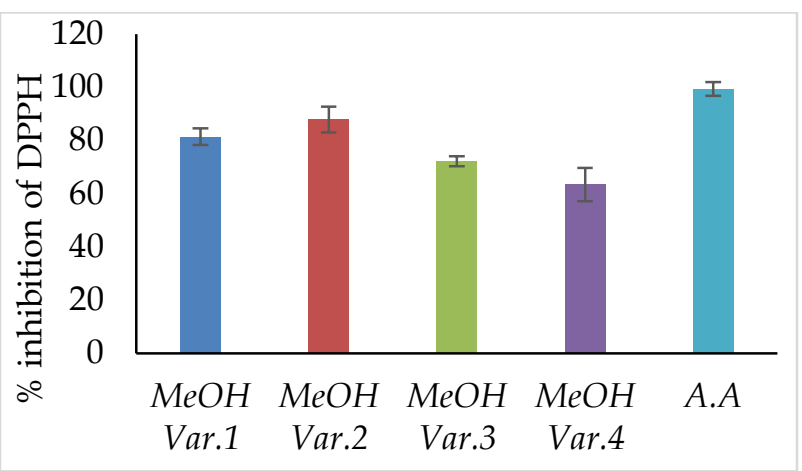

Figure 5. \% inhibition of DPPH. MeOH Var.1; $\mathrm{MeOH}$ Var.2: Variety 1, 2 Bakor (Fig flowers) of Bechar. $\mathrm{MeOH}$ Var.3; MeOH Var.4: Variety 3, 4 Bakor of Mascara

Compared to the positive control IC50 value 0.004 $\mathrm{mg} / \mathrm{g}$ DW, the lowest IC50 equal to $0.185 \mathrm{mg} / \mathrm{g}$ DW was deduced for methanolic extract of Bechar (MeOH Var.2), which chelated $87.9 \pm 1.23 \%$ of the $\mathrm{DPPH}$ free radical. However, the extract $\mathrm{MeOH}$ Var.4 has presented the lowest \% IP of $63.5 \pm 0.87 \%$ with an IC50 value of $0.448 \mathrm{mg} / \mathrm{g}$ DW. Our results showed a statistically significant difference between studied extracts and positive controls $(p<0.05)$.

Table 1. IC50 value of fig flowers fruits methanolic extracts.

\begin{tabular}{ll}
\hline Varieties of fig flowers (Bakor) & IC50 (mg/mL) \\
\hline MeOH Var.1 & $0.260^{\mathrm{A}}$ \\
$\mathrm{MeOH}$ Var.2 & $0.185^{\mathrm{B}}$ \\
$\mathrm{MeOH}$ Var.3 & $0.345^{\mathrm{C}}$ \\
$\mathrm{MeOH}$ Var.4 & $0.448^{\mathrm{D}}$ \\
$\mathrm{A} . \mathrm{A}$ & $0.004^{\mathrm{E}}$ \\
\hline $\mathrm{MeOH}$ Var.1; MeOH Var.2: Variety 1, 2 Bakor (Fig flowers) \\
of Bechar. MeOH Var.3; MeOH Var.4: Variety 3, 4 Bakor of \\
Mascara. A.A: ascorbic acid. Capital letters (A-B) and \\
lowercase letters (a-b) indicate significant differences at \\
p<0.05.
\end{tabular}

The high TPL and TFL levels measured can explain widely such a considerable percent of inhibition. Phenolics are the most effective antioxidants, which function as free radical scavengers, and absorb oxygen radicals $[32,33]$, because of their acidity, ability to transfer electrons and characteristic benzene rings [34]. Solomon et al. 2006 have proven that, compared to the fruit pulp, fruit skins have the most contribution to phytochemicals amounts and antioxidant capacity and both dark- and browncolored fig varieties are the most effective ones by their important amounts of flavonoids, polyphenols, and anthocyanins.

Besides, anthocyanins compounds of the dark- and brown-colored fig skin varieties contribute to 36 and $28 \%$ of their total antioxidant capacity [35]. 
Table 2. The correlation coefficient among antioxidant capacity tests, total flavonoid level, total anthocyanins level, total phenolic level, and tannins level.

\begin{tabular}{llllll}
\hline $\begin{array}{l}\text { MeOH } \\
\text { Var.1 }\end{array}$ & DPPH & TAC & $\begin{array}{l}\text { MeOH } \\
\text { Var.3 }\end{array}$ & DPPH & TAC \\
\hline TFL & $0.812^{\mathrm{A}}$ & $0.531^{\mathrm{a}}$ & TFL & $0.954^{\mathrm{A}}$ & $0.208^{\mathrm{a}}$ \\
TPL & $0.873^{\mathrm{A}}$ & $0.715^{\mathrm{b}}$ & TPL & $0.943^{\mathrm{B}}$ & $0.681^{\mathrm{b}}$ \\
TAL & $0.601^{\mathrm{A}}$ & $0.224^{\mathrm{c}}$ & TAL & $0.176^{\mathrm{C}}$ & $0.566^{\mathrm{c}}$ \\
$\mathbf{C T L}$ & $0.730^{\mathrm{A}}$ & $0.478^{\mathrm{d}}$ & $\mathrm{CTL}$ & $0.658^{\mathrm{D}}$ & $0.619^{\mathrm{b}}$ \\
\hline $\mathbf{M e O H}$ & DPPH & TAC & $\mathbf{M e O H}$ & DPPH & TAC \\
Var.2 & & & Var.4 & & \\
\hline TFL & $0.914^{\mathrm{A}}$ & $0.574^{\mathrm{a}}$ & TFL & $0.507^{\mathrm{A}}$ & $0.288^{\mathrm{a}}$ \\
TPL & $0.948^{\mathrm{B}}$ & $0.724^{\mathrm{b}}$ & TPL & $0.426^{\mathrm{A}}$ & $0.397^{\mathrm{b}}$ \\
TAL & $0.632^{\mathrm{C}}$ & $0.587^{\mathrm{c}}$ & TAL & $0.311^{\mathrm{A}}$ & $0.141^{\mathrm{c}}$ \\
CTL & $0.972^{\mathrm{D}}$ & $0.598^{\mathrm{d}}$ & CTL & $0.529^{\mathrm{A}}$ & $0.336^{\mathrm{b}}$ \\
\hline
\end{tabular}

TFL: Total Flavonoids Level, TAL: Total Anthocyanins Level, TPL: Total phenolics Level, CTL: Condensed Tannins Level, TAC: Total antioxidant capacity. $\mathrm{MeOH}$ Var.1; MeOH Var.2: Variety 1, 2 Bakor (Fig flowers) of Bechar. $\mathrm{MeOH}$ Var.3; $\mathrm{MeOH}$ Var.4: Variety 3, 4 Bakor of Mascara. Capital letters (A-B) and lowercase letters (a-b) indicate significant differences at $p<0.05$.

The total antioxidant capacity ranged from 63.5 to $92.1 \mathrm{mg} \mathrm{AAE} / \mathrm{g} \mathrm{dw}$ for $\mathrm{MeOH}$ Var.2 and $\mathrm{MeOH}$ Var.1, respectively in comparison with ascorbic acid $98.2 \pm 1.43 \mathrm{mg} \mathrm{AAE} / \mathrm{g} \mathrm{dw}$.

The total antioxidant capacity estimated for methanolic extracts of fig varieties fruits from the same region (Mascara) as our studied fig-flowers varieties 3, 4 (El Bordj, Ghriss) was ranged from 68.8 to $88.6 \mathrm{mg} \mathrm{AAC} / \mathrm{g}$ DW and the highest values were observed for the ethanolic extracts. Also, the max of the total tannin content of methanolic extracts was max of $122.35 \mathrm{mg}$ AAE/g DW [36].

According to the statistical analysis, separately, there are non-significant differences between the two fig varieties of Bechar: Var.1 (Lahmar), Var.2 (Ouakda) and also no significant differences between fig varieties originated of mascara Var.3 (El Bordj), Var.4 (Ghriss) $(P>0,05)$.

A positive and strong correlation was registered between the antioxidant capacity of plant extract and its total phenolic composition [37, 38, 39, 40, 41]. In vitro tests have shown that dried fig fruits possess a significant antioxidant capacity subsequently to their human consumption. As mentioned previously, the total antioxidant capacity correlated well with anthocyanins and phenolic compositions ( $R=0.989, R=0.515)$, but the correlation is low with the flavonoid amount $\mathrm{R}=0.248[15,42]$. However, the existence of other unidentified molecules with antioxidant properties in those extracts can not be overlooked. Peel extracts of fig fruits had a higher ability to scavenger free radicals, at all concentrations than pulp extracts with IC50 values of 80.04 and $28.85 \mathrm{mg} / \mathrm{mL}$. For the pulp, IC50 values were 105.85 and $176.88 \mathrm{mg} / \mathrm{mL}$ [43]. Results showed a positive and strong correlation between antioxidant capacity and different phytochemical compounds amounts. Phenolics and tannins components of $\mathrm{MeOH}$ Var.2 have an appreciable correlation with DPPH radical test $\mathrm{R} 2=0.948$ and $\mathrm{R} 2$ $=0.972$, respectively. Total phenolics had a strong correlation with the DPPH radical test $(\mathrm{R} 2=0.948)$. Furthermore, an important relation between both total flavonoids and total phenolics and DPPH radical presented by the extract $\mathrm{MeOH}$ Var. 3 with $\mathrm{R} 2$ $=0.954$ and R2 $=0.943$, respectively. A high correlation coefficient was deduced between antioxidant capacity and the levels of polyphenols and anthocyanins with R2 $=0.985$ and R2 $=0.992$, respectively [34]. The differences observed in the antioxidant capacity of plant extracts can be related to certain parameters like those that the solvent used for extraction, its polarity, and the tests used [44]. Moreover, as the mechanisms of antioxidant effect are dissimilar and the most natural antioxidants are multifunctional, it is important to use various antioxidant capacity tests to take a global observation of it.

\section{Conclusion}

The important antioxidant capacity of methanolic extracts of fig flowers fruits is impressive and probably it is the result of their exceptional richness in phenolic compounds. Such bioactive molecules reacting as natural antioxidants and then, they are well known to display a positive impact on human health and can be considered for future uses as antioxidant components in agro-food industries. The Algerian flora known for its high richness and biodiversity as well as Algerian folk medicine is also considered as an appreciable source of both new drugs and bioactive molecules since ancient times. Future studies will be needed to elucidate more and more medicinal plants and traditional preparations used for therapeutic purposes.

\section{Conflict of Interest}

The authors declare that they have no competing interests. 


\section{Acknowledgments}

The authors are grateful for the technical and financial support provided by Dr. Messaoudi Mohammed. Special thanks extended to Dr. Merah Maroua for her undeniable technical and theoretical assistance.

\section{References}

1. Juan ME, Gonzalez Pons, E, Planas JM. Multidrug resistance proteins restrain the intestinal absorption of trans-resveratrol in rats. The Journal of Nutrition. 2010 Mar 1;140(3): 489-495. https://doi.org/10.3945/jn.109.114959

2. Lako J, Trenerry VC, Wahlqvist M, Wattanapenpaiboon N, Sotheeswaran S, Premier R. Phytochemical flavonols, carotenoids and the antioxidant properties of a wide selection of Fijian fruit, vegetables and other readily available foods. Food Chemistry. 2007 Jan 1;101(4):1727-41. https://doi.org/10.1016/j.foodchem.2006.01.031

3. Liu RH. Potential synergy of phytochemicals in cancer prevention: mechanism of action. The Journal of nutrition. 2004 Dec https://doi.org/10.1093/jn/134.12.3479S 1;134(12):3479S-85S

4. Fukumoto LR, Mazza G. Assessing antioxidant and prooxidant activities of phenolic compounds. Journal of agricultural and food chemistry. 2000 Aug 21;48(8):3597-604. https://doi.org/10.1021/jf000220w

5. Mahmood A, Mahmood A, Malik RN. Indigenous knowledge of medicinal plants from Leepa valley, Azad Jammu and Kashmir, Pakistan. Journal of ethnopharmacology. 2012 Aug 30;143(1):338-46. https:// doi.org/10.1016/j.jep.2012.06.046

6. Rates SM. Plants as source of drugs. Toxicon. 2001 May 1;39(5):603-13. 0101(00)00154-9

7. Mars M. Fig (Ficus carica L.) genetic resources and breeding. InII International Symposium on Fig 6052001 May 7 (pp. 1927). https:/ / doi.org/10.17660/ ActaHortic.2003.605.1

8. Flaishman MA, Rodov V, Stover E. The fig: botany, horticulture, and breeding. Horticultural reviews. 2008;34. https:// doi.org/10.1002/9780470380147.ch2

9. Patil VV, Patil VR. Ficus carica Linn.-an overview. Research Journal of Medicinal Plant. 2011;5(3):246-53. https://doi.org/10.3923/rjmp.2011.246.253

10. Robaine P. La figue mûre : Reproduction particulière du figuier méditerranéen Ficus carica L. Association des Botanistes Lorrains Willemetia. 2014;82: 13 p.

11. Paquereau J. Au Jardin des Plantes de la Bible Botanique, symboles et usages. Edition Samuel six Editeur Institut pour le développement Forestier, Paris. 2013:416.

12. Pelletier E, Campbell P, Denizeau F. Ecotoxicologie moléculaire. Edition Press de l'université de Québec. 2003:182.

13. Bag GC, Devi PG, Bhaigyabati TH. Assessment of total flavonoid content and antioxidant activity of methanolic rhizome extract of three Hedychium species of Manipur valley. International Journal of Pharmaceutical Sciences Review and Research. 2015 Jan;30(1):154-9.

14. Grigoraş CG. Valorisation des fruits et des sous-produits de l'industrie de transformation des fruits par extraction des composés bioactifs (Doctoral dissertation, Université d'Orléans). 2012;246

15. Chawla A, Kaur R, Sharma AK. Ficus carica Linn.: A review on its pharmacognostic, phytochemical and pharmacological aspects. International Journal of Pharmaceutical and Phytopharmacological Research. 2012;1(4):215-32.

16. Nicole T, François G. Des fruits et des graines comestibles du monde entier. Lavoisier; 2013 Oct 15. 727.
17. BENHAMMOU N. Activité antioxydante des extraits des composés phénoliques de dix plantes médicinales de l'Ouest et du Sud-Ouest Algérien (Doctoral dissertation). 2012.

18. Sembiring EN, Elya B, Sauriasari R. Phytochemical screening, total flavonoid and total phenolic content and antioxidant activity of different parts of Caesalpinia bonduc (L.) Roxb. Pharmacognosy journal. 2018;10(1). https://doi.org/10.5530/pj.2018.1.22

19. Hebi M, Eddouks M. Évaluation de l'activité antioxydante de Stevia rebaudiana. Phytothérapie. 2016 Feb 1;14(1):17-22. https://doi.org/10.1007/s10298-015-0999-y

20. El-Haci IA, Atik-Bekkara F, Didi A, Gherib M, Didi MA. Teneurs en polyphénols et pouvoir antioxydant d'une plante médicinale endémique du Sahara algérien. Phytothérapie. 2012 Oct 1;10(5):280-5. https://doi.org/10.1007/s10298-0120726-x

21. Ercisli S, Tosun M, Karlidag H, Dzubur A, Hadziabulic S, Aliman Y. Color and antioxidant characteristics of some fresh fig (Ficus carica L.) genotypes from Northeastern Turkey. Plant Foods for Human Nutrition. 2012 Sep 1;67(3):271-6. https://doi.org/10.1007/s11130-012-0292-2

22. Julkunen-Tiitto R. Phenolic constituents in the leaves of northern willows: methods for the analysis of certain phenolics. Journal of agricultural and food chemistry. 1985 Mar;33(2):213-7. https://doi.org/10.1021/jf00062a013

23. Ba K, Tine E, Destain J, Cissé N, Thonart P. Étude comparative des composés phénoliques, du pouvoir antioxydant de différentes variétés de sorgho sénégalais et des enzymes amylolytiques de leur malt. Biotechnologie, Agronomie, Société et Environnement. 2010;14(1):131-9.

24. Mahmoudi S, Khali M, Mahmoudi N. Etude de l'extraction des composés phénoliques de différentes parties de la fleur d'artichaut (Cynara scolymus L.). Nature \& Technology. 2013 Jun 1(9):35.

25. Sánchez-Moreno C, Larrauri JA, Saura-Calixto F. A procedure to measure the antiradical efficiency of polyphenols. Journal of the Science of Food and Agriculture. 1998 Feb;76(2):270-6. https://doi.org/10.1002/(SICI)10970010(199802)76:2<270::AID-JSFA945>3.0.CO;2-9

26. Doukani K, Tabak S, Derrriche A, Hacini Z. Étude physicochimique et phyto-chimique de quelques types de miels Algériens. Revue Ecologie-Environnement. 2014;10:37-49.

27. Fabri RL, Nogueira MS, Braga FG, Coimbra ES, Scio E. Mitracarpus frigidus aerial parts exhibited potent antimicrobial, antileishmanial, and antioxidant effects. Bioresource Technology. 2009 Jan 1;100(1):428-33. https://doi.org/10.1016/j.biortech.2008.05.053

28. Aguilar Urbano M, Pineda Priego $M$, Prieto P. Spectrophotometric quantitation of antioxidant capacity through the formation of a phosphomolybdenum complex: specific application to the determination of vitamin E1. Anal Biochem. https://doi.org/10.1006/abio.1999.4019

29. Çalişkan O, Polat AA. Phytochemical and antioxidant properties of selected fig (Ficus carica L.) accessions from the eastern Mediterranean region of Turkey. Scientia Horticulturae. 2011 May 10;128(4):473-8. https://doi.org/10.1016/j.scienta.2011.02.023

30. Daniel M, Topo E. Analysis of nutrients, total phenols and antioxidant activity of Ficus sansibarica warb. fruits from Eastern Botswana. Journal of Drug Delivery and Therapeutics. $2012 \quad$ Nov 11;2(6). https:/ / doi.org/10.22270/jddt.v2i6.318

31. Vallejo F, Marín JG, Tomás-Barberán FA. Phenolic compound content of fresh and dried figs (Ficus carica L.). Food Chemistry. 2012 Feb 1;130(3):485-92. https:// doi.org/10.1016 /j.foodchem.2011.07.032

32. Halliwell B, Aeschbach R, Loliger J, Aruoma, OI. The characterization of antioxidants. Food Chem Tox. 
1995;33:601-617. https://doi.org/10.1016/02786915(95)00024-V

33. Aliyu AB, Musa AM, Oshanimi JA, Ibrahim HA, Oyewale AO. Phytochemical analyses and mineral elements composition of some medicinal plants of Northern Nigeria. Nigerian Journal of Pharmaceutical Sciences. 2008 Mar;7(1):119-25.

34. Brown RH. Free radicals, programmed cell death and muscular dystrophy. Current opinion in neurology. 1995 Oct 1;8(5):373-8. https://doi.org/10.1097/00019052-19951000000009

35. Solomon A, Golubowicz S, Yablowicz Z, Grossman S, Bergman M, Gottlieb HE, Altman A, Kerem Z, Flaishman MA. Antioxidant activities and anthocyanin content of fresh fruits of common fig (Ficus carica L.). Journal of agricultural and food chemistry. 2006 Oct 4;54(20):7717-23. https://doi.org/10.1021/jf060497h

36. Benmaghnia S, Meddah B, Tir-Touil A, Hernández Ja. Phytochemical analysis, antioxidant and antimicrobial activities of three samples of dried figs (Ficus carica L.) from the region of mascara. Journal of Microbiology, Biotechnology and Food Sciences. 2019 Jan 12;2019:208-15. https:// doi.org/10.15414/jmbfs.2019.9.2.208-215

37. Djeridane A, Yousfi M, Nadjemi B, Boutassouna D, Stocker P, Vidal N. Antioxidant activity of some Algerian medicinal plants extracts containing phenolic compounds. Food chemistry. 2006 Aug 1;97(4):654-60. https://doi.org/10.1016/j.foodchem.2005.04.028
38. Turkmen N, Velioglu YS, Sari F, Polat G. Effect of extraction conditions on measured total polyphenol contents and antioxidant and antibacterial activities of black tea. Molecules. 2007 Mar;12(3):484-96. https:// doi.org/10.3390/12030484

39. Tawaha K, Alali FQ, Gharaibeh M, Mohammad M, El-Elimat T. Antioxidant activity and total phenolic content of selected Jordanian plant species. Food chemistry. 2007 Jan 1;104(4):1372-8. https:// doi.org/10.1016/j.foodchem.2007.01.064

40. Wojdyło A, Oszmiański J, Czemerys R. Antioxidant activity and phenolic compounds in 32 selected herbs. Food chemistry. $\quad 2007 \quad$ Jan 1;105(3):940-9. https://doi.org/10.1016/j.foodchem.2007.04.038

41. Wong CC, Li HB, Cheng KW, Chen F. A systematic survey of antioxidant activity of 30 Chinese medicinal plants using the ferric reducing antioxidant power assay. Food chemistry. 2006 Aug 1;97(4):705-11. https://doi.org/10.1016/j.foodchem.2005.05.049

42. Raj SJ, Joseph B. Pharmacognostic and traditional properties of Cissus quadrancularis Linn-An overview. International Journal of Pharma and Bio Sciences2011. 2011;2(1):131-9.

43. Antolovich M, Prenzler PD, Patsalides E, McDonald S, Robards K. Methods for testing antioxidant activity. Analyst. 2002;127(1):183-98. https://doi.org/10.1039/b009171p

44. Fu L, Xu BT, Xu XR, Qin XS, Gan RY, Li HB. Antioxidant capacities and total phenolic contents of 56 wild fruits from South China. Molecules. 2010 Dec;15(12):8602-17. https://doi.org/10.3390/molecules15128602 